\title{
Varsakasvatus Suomessa
}

Seppo Hyyppä ${ }^{1)}$, Susanna Särkijärvi ${ }^{1)}$, Niina Tolvanen $^{2)}$, Anna-Kaisa Myllykoski $^{2}$, Emma Laakkonen $^{2)}$ ja Hanna-Leena Lindman ${ }^{2)}$

${ }^{1)}$ MTT, Hevostalous, Opistontie 10 A 1, 32100 Ypäjä, etunimi.sukunimi@mtt.fi

${ }^{2)}$ Hämeen ammattikorkeakoulu, 31310 Mustiala

\section{Tiivistelmä}

Suomen hevosmäärä on kasvanut viime vuosikymmenet tasaisesti ja nyt hevosia on noin 70000 . Suomenhevosista kaikki ja lämminveriravureistakin pääosa on kotimaista kasvatusta. Ratsujen kasvatus on ollut vähäistä, mutta kiinnostus siihenkin on lisääntynyt viime vuosina. Valtaosalla kasvattajista on vain 1 tai 2 siitostammaa ja aloittelevia kasvattajia on paljon. Kantavan tamman hoito ja ruokinta, varsominen sekä varsan hoito ja ruokinta vaativat kuitenkin kasvattajalta paljon osaamista ja huolellisuutta, jotta kaikki menisi hyvin.

Tämän tutkimuksen tarkoitus oli selvittää varsojen kasvatusolosuhteita, ruokintaa ja hoitokäytäntöjä Suomessa. Työ liittyy yhteispohjoismaiseen NKJ tutkimushankkeeseen: Group Housing Horses under Nordic conditions, jonka tavoitteena on parantaa hevosten ryhmäkasvatusolosuhteita.

Tutkimusaineistoa kerättiin tilakäynnein, jotka tehtiin 2009 helmi-maaliskuussa 20 hevostilalle Etelä-Suomessa. Tiloilla oli vuonna 2008 syntyneitä varsoja yhteensä 165 (2-23/tila). Varsat olivat suomenhevosia, lämminverisiä, puoliverisiä, arabeja, poneja sekä risteytyksiä. Ne olivat iältään 8-12 kk.

Osalla tiloista talli tai pihatto oli hevosen pitoon suunniteltu ja rakennettu rakennus. Joissakin paikoissa pihaton virkaa hoiti kolmiseinäinen katos. Rakennuksen iällä ei ollut aina suoraa yhteyttä tallin hevosystävällisyyteen ja viihtyvyyteen. Vaikka parannettavaakin oli, useimmat tilat täyttivät lain asettamat vaatimukset hevosten pitopaikoille. Useimmilla tiloilla varsoilla oli hyvät mahdollisuudet liikkua ryhmässä. Tarhojen puhdistuksessa on osalla parannettavaa.

Varsat olivat hyväkuntoisia muutamaa poikkeusta lukuun ottamatta. Tilaratkaisu tuntui vaikuttavan käsittelymääriä enemmän varsojen lähestyttävyyteen tarhassa, sillä lähes kaikki pihattovarsat tulivat tutkimaan uusia ihmisiä, kun taas muutama yksittäiskarsinassa asuva ei päästänyt lähellekään.

Korsirehuruokinnassa noudatetaan hyvin varsojen luontaista syömiskäyttäytymistä pitämällä sitä vapaasti saatavilla tai jakamalla sitä useita kertoja päivässä. Korsirehun rehuanalyysejä pitäisi tehdä ja hyödyntää nykyistä useammin, jotta varsat saavat parhaat mahdolliset lähtökohdat kasvuun. Väkirehuruokinnassa olisi parannettavaa tiloilla, joilla varsojen ruokailurauhaa ei taattu väkirehuruokinnan ajaksi. Varsojen juotto oli yllättävän usein kantoveden varassa. Kesäisin laiduntaminen on erittäin suositeltavaa kasvaville varsoill, mutta laidunten viljavuustutkimuksissa, kalkituksissa ja lannoituksissa on osalla tiloista parannettavaa.

Puutteellinen vasta-aineiden saanti tammanmaidosta voi johtaa jopa varsan menehtymiseen. Silti vain harvalla tilalla varmistetaan jokaiselta varsalta vasta-aineiden riittävä taso. Lähes kaikilla tiloilla huolehdittiin siitostammojen ja varsojen loishäädöistä ja rokotuksista hyvin. Lanta-analyysien teettäminen loisten varalta oli harvinaista. Monella tilalla on parannettavaa varsojen kavioiden hoidossa.

Asiasanat: hevonen, varsa, kasvatus, ruokinta, hoito 


\section{Johdanto}

Suomen hevosmäärä on ollut viimeiset vuosikymmenet tasaisessa kasvussa ja tällä hetkellä hevosia sekä poneja arvioidaan olevan yhteensä noin 70000 (Suomen Hippos 2009). Lämminveristen ravihevosten ja suomenhevosten määrät ovat pysyneet viime vuodet suurin piirtein samalla tasolla. Kasvu on tapahtunut ensisijaisesti poni- ja ratsuhevosten määrässä.

Kaikki suomenhevoset ja suurin osa lämminveriravureista on kotimaista kasvatusta. Lämminverisiä varsoja syntyy noin 1900 ja suomenhevosvarsoja noin 1300 vuodessa (Suomen Hippos 2009). Ratsujen kasvatus on ollut hyvin vähäistä, joten niiden, ja paljolti myös ponien, määrän kasvu pohjautuu ulkomaiseen tuontiin. Kiinnostus ratsujen kasvatukseen on kuitenkin lisääntynyt selvästi viime vuosina. Vuonna 1998 astutettuja ratsutammoja oli 100, vuonna 2003500 ja vuonna 2008 jo 800 kappaletta (Suomen Hippos 2009). Ponivarsoja syntyi vuonna 2007 noin 600 kappaletta (Suomen Hippos 2009).

Kasvattaminen ei yleisesti ottaen ole taloudellisesti kovin kannattavaa. Niinpä kaikki kasvatustoiminta on Suomessa pääosin pienimuotoista ja valtaosalla kasvattajista on vain 1 tai 2 siitostammaa. Moni kasvattaja on myös ensikertalaisena varsin kokematon. Osalla on vain tarkoituksena varsottaa oma tamma kerran eikä tavoitteena ole varsinainen kasvatustyön jatkaminen. Oriin valinta, kantavan tamman hoito ja ruokinta, varsominen sekä pikkuvarsan hoito ja ruokinta vaativat kuitenkin kasvattajalta paljon tietoa, osaamista ja huolellisuutta, jotta kaikki menisi hyvin.

Tämän tutkimuksen tarkoitus oli selvittää varsojen kasvatusolosuhteita, ruokintaa ja hoitokäytäntöjä Suomessa. Työ liittyy yhteispohjoismaiseen NKJ tutkimushankkeeseen, Group Housing Horses under Nordic conditions, jonka tavoitteena on parantaa hevosten ryhmäkasvatusolosuhteita.

\section{Aineisto ja menetelmät}

Tutkimusta varten käytiin 20 hevostilalla Etelä-Suomessa vuoden 2009 helmi-maaliskuun aikana selvittämässä varsojen kasvatusolosuhteita, ruokintaa ja hoitokäytäntöjä. Tiloilla oli vuonna 2008 syntyneitä varsoja yhteensä 165, mikä on noin $4 \%$ koko ikäluokasta. Tilakohtaisesti varsojen määrä vaihteli 2-23 varsaan. Varsat olivat suomenhevosia, lämminverisiä, puoliverisiä, arabeja, poneja sekä risteytyksiä. Tutkimuksessa keskityttiin vuonna 2008 syntyneisiin varsoihin, jotka olivat tilakäyntien aikaan iältään 8-12 kk.

\section{Tulokset ja tulosten tarkastelu}

\section{Tilat}

Yleisin vieroitettujen varsojen kasvatustapa oli pitää niitä pihatossa. Näin tapahtui 11 hevostilalla. Kahdella tilalla varsat olivat osan vuodesta tallissa ja osan pihatossa. Ryhmäkarsinaratkaisuja oli kolmella tilalla ja tavanomaisissa yksittäiskarsinoissa varsoja pidettiin kahdella tilalla. Kahdella tilalla oli käytössä sekä ryhmä- että yksittäiskarsinoita.

Yksi hevosten hyvinvointiin vaikuttava tekijä on riittävän suuri tila. Eläinsuojelumääräyksissä hevosten yksittäiskarsinan minimitila on säkäkorkeudesta riippuen 4-8 m² (MMMp 14/EEO1998). Ryhmäkarsinassa on oltava tilaa kutakin siellä pidettävää hevosta kohden vähintään $50 \%$ yksittäiskarsinan tilasta. Varsojen pitopaikkojen kokonaispinta-alat vaihtelivat $6 \mathrm{~m}^{2}$ karsinasta $180 \mathrm{~m}^{2}$ makuuhalliin. Keskimäärin tilaa varsaa kohti oli $9,75 \mathrm{~m}^{2}$. Sekä suurin $\left(22,5 \mathrm{~m}^{2}\right)$ että pienin $\left(4 \mathrm{~m}^{2}\right)$ tila olivat pihatoissa. Kaikki tilat täyttivät eläinsuojelumääräyksen minimit pinta-alojen osalta.

Pinta-alojen lisäksi vuoden 2014 alusta kaikkien tallien sisäkorkeuden on oltava vähintään hevosen säkäkorkeus kerrottuna luvulla 1,5, kuitenkin aina vähintään 2,2 m (MMMp 14/EEO1998). Tallien sisäkorkeudet olivat 2-6 metriä. Yhdellä tilalla joudutaan tekemään toimenpiteitä ennen määräajan umpeutumista.

\section{Ilman laatu}


Eläinsuojan ilmanvaihdon on oltava sellainen, että ilman kosteus, pölyn määrä tai haitallisten kaasujen pitoisuudet eivät kohoa haitallisen korkeiksi (MMMp 14/EEO1998). Ohjeelliset raja-arvot on annettu ammoniakille, rikkivedylle, hiilidioksidille, orgaaniselle pölylle ja ilman suhteelliselle kosteudelle. Koneellinen ilmanvaihto oli vain $15 \%$ tiloista; 1 pihatossa, 1 karsinatallissa, 1 ryhmäkarsinatilalla. Painovoimainen ilmanvaihto oli 55 \% tiloista. Erillisiä ilmanvaihtohormeja ei ollut lainkaan $30 \%$ talleista, nämä olivat kaikki pihattoja. Tallitilan lämmitysmahdollisuus oli $10 \%$ talleista. Ilman kaasu ja hiukkaspitoisuuksia ei mitattu tässä tutkimuksessa.

Tallin ilman laatuun vaikuttavat ilmastoinnin lisäksi myös kuivike ja karsinoiden puhdistus. Yleisimmät kuivikemateriaalit ovat olki, turve ja sahanpuru. Näistä turpeella on aivan selvästi paras virtsan ja ammoniakin sitomiskyky. Pelkästään olkea käyttää $45 \%$, vain turvetta $30 \%$, oljen ja turpeen yhdistelmää $15 \%$, pelkkää purua $5 \%$ sekä purun ja turpeen sekoitusta $5 \%$ tutkimuksen talleista. Olkea suositaan pihatoissa. Turve on suosituin kuivike yksittäiskarsinoissa.

Kaikki yksittäiskarsinat siivotaan päivittäin, eikä niissä käytetä kestokuivikepatjaa. Ryhmäkarsinoita siivotaan päivittäin - 3 kertaa vuodessa. Suurimmassa osassa pihattoja (45,5 \%) käytetään kestokuivikepohjaa, joka tyhjennetään kerran vuodessa. Osaa pihatoista tyhjennetään useammin, suurin tyhjennystiheys tutkituilla talleilla on 5 kertaa vuodessa. $27 \%$ pihattotalleista näkyvät lannat poistetaan päivittäin. Vain yhdellä tilalla varsat olivat likaisia ja niillä oli liian vähän kuivikkeita.

\section{Liikunta}

Kaikki varsat ulkoilivat ryhmissä. Ryhmässä oli vain samanikäisiä varsoja $65 \%$ tiloista. Tammat ja oriit pidettiin yhdessä $45 \%$ ja erillään $40 \%$ tiloista. Kolmella tallilla oli vain samaa sukupuolta olevia varsoja tutkimuksen tekohetkellä.

Varsat suljettiin pihattoon yöksi yhdellä tilalla, muissa pihatoissa (50\% kaikista talleista) ne saavat liikkua vapaasti sisään ja ulos 24 h/vrk. Varsat ulkoilevat 10 - 15 h/vrk 25 \%, 5 - 10 h/vrk 15 $\%$ ja 0 - 5 h/vrk $10 \%$ talleista. Sää vaikutti suuresti tarhausaikaan muissa kuin pihatossa.

Tarhojen pohjia oli kunnostettu 65 \% tiloista, muilla ne olivat luonnontilassa. Tilavierailuiden aikaan tarhojen ja pihattotarhojen pohjat olivat pääosin hyvässä kunnossa, koska oli talvi, lunta ja pakkasta. Pihatoissa varsoilla on säänsuoja, mutta yhdelläkään karsina- tai ryhmäkarsinatallilla ei tarhassa ollut katosta.

\section{Ruokinta}

Varsan ensimmäistä elinvuotta leimaa voimakas kasvu. Niinpä mahdolliset tuki- ja liikuntaelimistön kehityshäiriöt ilmaantuvat yleensä tänä aikana. Syitä kehityshäiriöihin voivat olla vääränlainen ruokinta tai liian rankka liikunta ja geneettiset tekijät. Koska geneettisiin tekijöihin ei enää voi varsan synnyttyä vaikuttaa, korostuu oikeanlaisen liikunnan ja etenkin ravinnon merkitys.

Rehujen hygieenisen laadun pystyy hyvinkin päättelemään ilman analyysejä, mutta rehujen sisältämien ravinto- ja kivennäisaineiden pitoisuudet saadaan luotettavasti selville ainoastaan teettämällä rehuista analyysi. Karkearehuista oli teetetty rehuanalyysit 10 tilalla. Vain puolella näistä tietoa myös hyödynnettiin laskemalla rehuannokset ruokintaohjelmalla tai käsin. Muut luottivat silmämääräiseen arvioon rehujen annostelussa. Analyysitulokset saatiin käyttöön viideltä tilalta. Viideltä tilalta otettiin näytteet tilakäynnin yhteydessä ja rehuanalyysit teetettiin Valion Seinäjoen aluelaboratoriossa.

Kuiva heinä oli ainoa karkearehu yhdellä tilalla. Karkearehua oli vapaasti saatavilla 13 tilalla ja muut jakoivat sitä vähintään 3 kertaa päivässä. Kauraa käytettiin väkirehuna 16 tilalla, muilla oli käytössä teollinen rehu. Yleensä väkirehut jaettiin kahdesti päivässä (14 tilaa). Vain kerran päivässä väkirehut jaettiin kahdella ja kolmasti päivässä neljällä tilalla. Useimmat tilat (11 kpl) varmistivat jollakin tavalla, että jokainen varsa sai oman väkirehuannoksensa. Valkuaistäydennystä ei annettu kahdella tilalla. Soijarouhetta käytettiin 7 ja kaupallisia valmisteita 11 tilalla. Kaikki varsat saivat kivennäisiä. Kolmella tilalla luotettiin vitamiinitarpeen täytyvän heinällä, kauralla ja kivennäisillä.

Juomavesi tuli automaatista 11 tilalla, muut hoitivat juoton kantovedellä. Juomapaikkoja on vain yksi varsaryhmää kohden 13 tilalla. 


\section{Ruokinnan sopivuus}

Tutkimuksessa ruokinnan sopivuus laskettiin ruokintaohjelma PC-Horsella kutakin varsaryhmää kohden. Silloin kun karkearehuista ei ollut käytettävissä rehuanalyysejä, käytettiin ohjelman valmiita rehuarvoja.

Energiaa varsat saivat laskujen mukaan varsin sopivasti ja enemmistö varsoista olikin lihavuuskunnoltaan normaaleja, 149 varsaa. Lihavahkoja oli 7 ja laihoja 9 kappaletta.

Varsojen sulavan raakavalkuaisen saanti oli hyvällä tasolla 12 tilalla. Liian vähän valkuaista varsat saivat 7 ja liikaa yhdellä tilalla. Ensimmäisenä rajoittavan aminohapon, lysiinin määrä oli kuitenkin riittävä 17 tilalla.

Vaikka kalsium/fosfori -suhde oli jokaisella tilalla normin mukainen, näiden kivennäisten määrä oli riittävä vain 10 tilalla. Myös muiden kivennäisten ja hivenaineiden saannissa esiintyi puutteita 14 tilalla. Vitamiinien saannissa oli puutteita $80 \%$ tiloista ja $70 \%$ oli puutetta luuston kehitykselle välttämättömästä D-vitamiinista.

\section{Nurmien hoito}

Laidunmaita oli hallinnassa 18 tilalla. Laidunnurmien viljavuustutkimus oli tehty vaaditun 5 vuoden välein 13 tilalla. Peltoja oli kalkittu 7 tilalla 5 vuoden sisällä. Lannoitteita ei käytetty lainkaan 2 tilalla. 6 tilalla ei osattu kertoa käytetyistä lannoitteista ja määristä.

\section{Hoitokäytännöt}

\section{Käsittely}

Mitä varhaisemmassa vaiheessa varsa oppii luottamaan ja kunnioittamaan käsittelijäänsä johtajana, sitä vaivattomampaa ja turvallisempaa on sen käsittely. Myöhemmin on myös helpompi edetä sen varsinaisessa koulutuksessa. Pikkuvarsalle opetettavia asioita ovat mm. riimun laitto, kiinni oleminen, harjaaminen, väistäminen sivuun, peruuttaminen, taluttaminen sekä jalkojen nostelu ja kavioiden puhdistus.

Osa käsitteli varsoja vain pakollisten hoitojen, kuten kavioiden vuolun ja rokotusten yhteydessä. Useimmat opettavat varsat talutukseen ja seisomaan kiinnisidottuna. Joissain paikoissa varsoja irtohypytetään, käytetään näyttelyissä, mitataan tai punnitaan. Päivittäin varsoja käsiteltiin 60 \%, 2-4 kertaa viikossa $10 \%$, kerran viikossa $10 \%$ ja kerran kuukaudessa $10 \%$ paikoista. Silloin tällöin varsoja käsiteltiin $10 \%$ tiloista.

Vuonna 2008 syntyneiden varsojen kanssa oli selvitty ilman henkilötapaturmia ja vakavia vaaratilanteita $80 \%$ talleista. Yhdellä tallilla oli tapahtunut vaaratilanne. Tapaturma oli sattunut kolmella tallilla; varsa puri hoitajaansa, varsa juoksi hoitajan yli ja varsa pääsi potkaisemaan.

Varsoilla ei ollut tapaturmia $60 \%$ talleista. Varsoille sattuneista 8 tapaturmasta vakavin oli reisiluun katkeaminen, joka johti varsan lopetukseen. Muut tapaturmat ovat olleet haavoja, pieniä naarmuja tai pieniä turvotuksia.

\section{Pikkuvarsan hoito}

Napaa pidetään yhtenä merkittävänä infektioporttina, jonka kautta taudin aiheuttajat voivat päästä kohta syntymän jälkeen varsaan. Napa hoidettiin 12 tilalla aina välittömästi syntymän jälkeen laimennetulla Betadinella, muilla vain jos syytä ilmeni. Napatulehdusta ei ollut esiintynyt.

Koska tamman istukka ei läpäise vasta-aineita, varsat syntyvät kokonaan ilman vasta-aineita. Saadakseen hyvän suojan taudinaiheuttajia vastaan varsan pitää juoda 11/2-2 l hyvälaatuista ternimaitoa ensimmäisten $12 \mathrm{~h}$ aikana.

Tammanmaidon vasta-ainepitoisuus tutkittiin aina neljällä ja puutetta epäiltäessä samoin neljällä tilalla, muilla ei koskaan. Jokaisesta varsasta otetaan verinäyte vasta-ainemääritystä varten kahdella tilalla, muilla silloin kun epäillään, että kaikki ei ole kunnossa. Ternimaitoa oli pakkasessa kaiken varalle 16 tilalla. 
Vasta-aineiden puutosta oli esiintynyt kahdella varsalla, jotka olivat kahdella eri tilalla. Toisesta tiedettiin, ettei sen emän ternimaito ole laadukasta ja varsalle tehtiin plasmansiirto. Toista varsaa ei ehditty hoitaa ajoissa ja se menehtyi.

Sikiöaikana varsan suoleen muodostuu tummaa ulostetta. Joskus tätä tahmeaa varsapihkaa on niin paljon, että varsa ei pysty ulostamaan sitä ilman apua. Yhdellä tilalla jokaiselle vastasyntyneelle annettiin aina peräruiske. Toisella sekoitetaan parafiiniöljyä ternimaidon sekaan rutiinisti. Varsapihkan takia hoitoa oli tarvinnut kaksi varsaa. Koska vain pari prosenttia varsoista tarvitse välttämättä hoitoa varsapihkan takia ja parafiiniöljy voi heikentää vasta-aineiden imeytymistä suolistosta, sen antaminen rutiininomaisesti jokaiselle varsalle ei ole perusteltua.

\section{Perusterveyden hoito}

Ensimmäinen loishäätö annettiin 1-2 kuukauden iässä 19 tilalla, yhdellä vasta syksyllä laidunkauden jälkeen. Jatkossa varsat saivat loishäädön kerran kuussa 6, 6-8 viikon välein 9 ja 3 kk välein 5 tilalla. Tammat madotettiin kolmasti vuodessa 2, neljästi vuodessa 16 ja useammin 2 tilalla. Tarhoja siivotaan päivittäin $20 \%$, kerran viikossa $20 \%$, kahdesti kuukaudessa $5 \%$, kahdesti vuodessa $10 \%$ ja kerran vuodessa $20 \%$ tiloista. $25 \%$ talleista tarhoja ei siivota lainkaan. Vain 4 tilalla oli otettu lanta-analyysi mahdollisen mato-ongelman ja matolääkkeiden tehon määrittämiseksi.

Hyvissä oloissa varsan kavioiden kasvaminen ja kuluminen tapahtuvat tasatahtiin, mutta siitä huolimatta varsan kaviot pitäisi tarkastaa ja tarvittaessa vuolla 2-4 viikon välein kuukauden iästä alkaen. Näin varmistetaan, että kaviot kuluvat tasaisesti, mikä taas on tärkeää jalka-asentojen kehityksen kannalta.

Osa varsoista olisi kaivannut kavioiden hoitoa nykyistä useammin. Varsojen kaviot hoidettiin vähintään 6 viikon välein 4, 8 viikon välein 3, 3 kk välein 1 ja tarpeen mukaan 12 tilalla. Näistä 12 tilasta kaviot oli hoidettu ensimmäisen kerran laidunkauden päättyessä yhdellä ja vieroituksen aikaan kolmella tilalla. Kavioita ei ollut hoidettu vielä kertaakaan yhdellä tilalla. Varsojen kavioista huolehtii yleensä koulutettu kengittäjä.

Synnynnäisiä jalkojen kehityshäiriöitä oli ollut kaikkien kartoitukseen osallistuneiden tilojen kaikista 2008 syntyneistä varsoista vain kahdella. Muita jalka-asentovirheitä sen sijaan esiintyi useammallakin tilalla. Osa näistäkin virheistä olisi ehkä ollut korjattavissa riittävän aikaisella asiaan puuttumisella. Viidellä varsalla oli käytetty liimakenkiä jalka-asentojen korjaamiseen.

Kaikilla tiloilla varsat rokotetaan. Tetanusta vastaan rokotti 19, influenssaa vastaan 15 ja herpestä vastaan 5 tilalla.

Ripulia oli ollut 7 tilalla. Se oli enimmäkseen lievää ja vain yhtä varsaa oli lääkitty. Kuudella varsalla, jotka olivat kaikki eri tiloilta, oli ollut ähky. Yksi varsa oli kuollut siihen. Varsojen hengitystietulehduksia oli ollut 6 tilalla. Suurin osa ei tarvinnut hoitoa, koska tauti oli lievää. Vain yhdellä varsalla oli ollut paiseinen keuhkotulehdus, joka oli saatu hoidettua. Pääntautia ei esiintynyt yhdelläkään tilalla.

\section{Johtopäätökset}

Osalla talli tai pihatto oli hevosen pitoon suunniteltu ja rakennettu rakennus. Toisilla pihaton virkaa hoitaa kolmiseinäinen katos. Rakennuksen iällä ei ollut aina suoraa yhteyttä tallin hevosystävällisyyteen ja viihtyvyyteen. Vaikka parannettavaakin oli, useimmat tilat täyttivät lain asettamat vaatimukset hevosten pitopaikoille.

Varsat olivat hyvän näköisiä ja hyväkuntoisia muutamaa poikkeusta lukuun ottamatta.

Useimmilla tiloilla varsoilla oli hyvät mahdollisuudet ryhmässä liikkumiseen. Muilla kuin pihatoissa olevilla ei tarhoissa ollut katoksia. Tarhojen puhdistuksessa on osalla parannettavaa.

Tilaratkaisu tuntui vaikuttavan käsittelymääriä enemmän varsojen lähestyttävyyteen tarhaolosuhteissa, sillä lähes kaikki pihattovarsat tulivat tutkimaan uusia ihmisiä, kun taas muutama yksittäiskarsinassa asuva ei päästänyt lähellekään.

Korsirehun rehuanalyysejä kannattaisi tehdä ja myös hyödyntää nykyistä useammin, jotta varsat voidaan ruokkia oikein ja ne saavat parhaat mahdolliset lähtökohdat optimaaliseen kasvuun ja kehitykseen. 
Korsirehuruokinnassa noudatetaan hyvin varsojen luontaista syömiskäyttäytymistä pitämällä korsirehua vapaasti saatavilla tai jakamalla sitä useita kertoja päivässä. Väkirehuruokinnassa olisi parannettavaa tiloilla, joilla varsojen ruokailurauhaa ei taattu väkirehuruokinnan ajaksi. Varsojen juotto oli yllättävän usein kantoveden varassa, mikä lisää runsaasti työn määrää.

Kesäisin laiduntaminen on erittäin suositeltavaa kasvaville varsoille, mutta laidunten viljavuustutkimuksissa, kalkituksissa ja lannoituksissa osalla tiloista on kuitenkin parannettavaa.

Vaikka vasta-aineiden puutoksen takia varsa voi menehtyä tulehdukseen nopeasti, vain harvalla tilalla varmistetaan jokaiselta varsoilta, että se on saanut riittävästi vasta-aineita. Vasta-aineiden puutos oli ollut syynä yhden varsan menehtymiseen.

Lähes kaikilla tiloilla huolehdittiin siitostammojen ja varsojen loishäädöistä ja rokotuksista hyvin. Lanta-analyysien teettäminen ei ollut yleistä. Isolla osalla tiloista on parannettavaa varsojen kavioiden hoidossa.

Vaikka suurimmalla osalla tiloista asiat ovat hyvässä kunnossa ja toiminta on ammattitaitoista, niin selvitys kuitenkin osoitti että neuvonnalle on selvästi tarvetta. Kasvattajille voisi olla hyötyä hyötyä esimerkiksi ravintotietouden lisäämisestä. Lisäksi olisi tarpeellista tiedottaa varsojen kaviohoidon tärkeydestä ja jalka-asentojen korjaamisen mahdollisuuksista.

\section{Kirjallisuus}

Suomen Hippos 2009 www.hippos.fi

MMMp 14/EEO1998 www.finlex.fi 